\title{
Organizing War and the Military in Society: A Systemic Perspective
}

\author{
Nicolas Hayoz \\ Associate Professor of Political Science, \\ Director of the Interdisciplinary Institute of Central and Eastern Europe, \\ University of Fribourg (Switzerland) \\ Address: Bd de Pérolles 90, 1700 Fribourg, Switzerland \\ E-mail: nicolas.hayoz@unifr.ch
}

\begin{abstract}
Sociology can analyze war and warfare under different aspects, for example, as a problem of collective violence. It has rather neglected another important aspect of war, as in the fact that war is also always an organizational phenomenon. In the last few years, several studies on war have been focusing on this aspect by using or referring to Niklas Luhmann's system theory. This paper looks at some of these aspects by critically asking how these sociological studies use Luhmann's theory in their analysis of war or war-related social structures. Luhmann's theory, particularly the theory of society based on the principle of functional differentiation, has a powerful explicative potential, particularly for the analysis of war and warfare. However, only a few studies are actually using Luhmann's theory in an adequate way by situating the concepts at the correct analytical level. War and "military systems" should be analyzed as organizational structures in society which are managed, first of all, by the political system, a function system of society, and which by no means excludes a multiplicity of interdependencies with other systems. A systemic perspective should also take regional "expressions" of society such as "military systems" in specific states or groups of states into account.
\end{abstract}

Keywords: war, organization, system theory, Niklas Luhmann, military systems, war society, militarization, functional differentiation

The semantics of war is being used more than ever in an inflammatory manner in society, particularly by politicians and journalists who can be sure to get the public's attention when referring to a war discourse and the exceptional state of affairs indicated by the affirmation that "we are in a state of war." Moreover, one can see how certain events such as terrorist attacks, usually handled by the judiciary system as criminal acts, are presented in the public space as warlike acts and can be used by the political system to justify specific measures such as declaring a state of emergency, or mobilizing national and international support and unity for the fight against real or imagined enemies. However, today one can also expect the public getting used to publicized declarations that governments have to win a "war against terrorism," or that a "propaganda war" is going on between states.

Could this be the starting point for a sociological analysis of war? Not really. However, the dialogues on war show that war is also about the circulation of the war semantic in

(C) Nicolas Hayoz, 2016

(C) Centre for Fundamental Sociology, 2016

DOI: $10.17323 / 1728-192 \mathrm{X}-2016-2-9-25$ 
public opinion. Of course, there are also real wars in the sense of collective violence between two groups a long way from here, that is, at the periphery of the "pacified" centers of modernity. Nevertheless, big powers are usually at war somewhere on the globe and can use war, particularly war rhetoric, to achieve diverse goals which may also include a distraction from internal problems. There is a sociology of war looking at war, particularly violence, as a phenomenon per se; there is another one focusing rather on the implications of war for military organization, state, and other social structures (Malešević, 2010: 45ff.). This paper positions itself rather along this second strand of research on warfare. It is not looking at a so-called 'bellicose tradition', or at collective violence. Rather, it is focused on specific aspects of war, particularly the organizational aspects, through the lens of systems theory, aiming at exploring the position of war in the architecture of Luhmann's theory of society.

It is rather trivial to say that war is also a social phenomenon. Sociological analysis has to go beyond this and use adequate concepts to describe war in its social meanings. This paper tries to do so by first outlining and presenting key concepts of Luhmann's system theory and his theory of society. These concepts are important for the understanding of the systemic aspects of a sociology of war. It goes without saying that Luhmann's theory is one of the most powerful theories with a high explicative potential for the analysis of modern society, its components and structures. Not surprisingly, in recent years, systemic analysis has been used in the studies of war. Several studies have been researching such topics as the organizational aspects of war, the idea of self-referential "military system" (Harste, 2004, 2009), the idea of a modernity described in terms of "war society" (Kruse, 2009, 2015), and finally, the relationship between war and the theory of functional differentiation, including the role of soldiers and inclusion (Kuchler, 2013a, 2013b). These sociological studies use Luhmann's system theory directly or indirectly as a theoretical framework in their studies on war. This paper will scrutinize several of them by looking at their theoretical aspects, and by asking how these sociological studies use Luhmann's theory of society in their analysis of war or war-related social structure. It is to say that this paper is an exercise in observing systemic observations by using the same theoretical framework. Then, we would like to put these approaches or studies in perspective by answering the question how two different levels of system formation, particularly in the case of war organizations and functional differentiation, can and should be understood and combined.

According to Luhmann, modern society and, as it is nowadays, world society, is based on communication (Luhmann, 1997a: 145ff., 2012: 83ff., 1997b, 1990). Communication is always communication within society. Describing society is necessarily a description of society where it can be contested by other descriptions. World communication, such as information technologies structures for example, cannot only be observed under technical aspects by the way they extend or circulate, for they are also differentiated in certain 
parts. In its attempt to identify the dominant social structure, sociology has always been focused on the way social differentiation is being organized. Modern society is based on functional communication, with communication following the logic of self-referential function systems such as the legal system, politics, the economy, science, art or education, and therefore, its dominant structure can be presented as functional differentiation. Since these systems are functional communication systems, they are seen in a particular perspective in society. To the extent that they are communicating about different things, they are distinguishing and differentiating themselves from societal communication based on their own principles. As basic components of modern society, they are reproducing world society as a unique global social system (Luhmann 1990, 1984: 557, 585). If functional differentiation is the dominant structure of world society, then it does not make sense to say that systems like the economic, scientific, or educational have not yet reached specific regions of the world. However, it may make sense to state that whole regions of the world have no chance or are not willing to realize functional differentiation, reaching out to modernity in the sense it is realized, for example, in the autonomy of scientific, economic, or political systems.

Without a doubt, world communication is continuously facilitated technically. Society and its events are present everywhere on the globe at any time. The more this is the case, the more one can see what is the case elsewhere, that is, what is being offered through the entire world's functions systems. Comparisons, and therefore also competition, between states and regions are made possible. On the other hand, when looking at the communicative side of society, and at the technological side of communication in modern society, one can easily see that the possibility to participate in, use, or produce modern communication technology is unevenly distributed worldwide.

This is also what can be expected in modern society where the dominant structure of functional differentiation allows and produces many regional experiments. For example, here one may think of the organization of political systems on a national level (states), or of the question as to how political decision-making should be organized (democracy), or to what extent states should control the production of goods and capital on their territory, or to what extent states can create the technological conditions to produce the new technologies necessary for "science society." Huge regional variations must be expected in world society in which both the dynamics of specific autonomous systems, such as the economy ("global capitalism"), and states reproduce and continuously create vast differences between countries and regions (Stichweh, 2006, 2000; Luhmann, 1997: 145-171). Given the worldwide disparities in regard to power and wealth, one may expect that the "face" of functional differentiation, that is, the way its components and system levels (society, organizations and interactions) interact with one another, varies considerably from one region of the world to the next. However, if certain countries attempt to counter authoritarianism or even communism against what they call liberal modernity, that does not put them on the side of a different modernity. On the contrary, they are part of the same modern society, even when they pretend to be different from the "West," or when they have another economic and military organization, or are going to war. The 
same may be said in regard to the economic integration in a globalized word economy of countries that do not participate in certain organizations, or insist on the coexistence of different forms of capitalism. However, even insisting on differences is communication in the context of globalized world society. Likewise, when states controlling specific territories try to block or control certain achievements of that modernity, such as democracy in the form of political opposition, the legal system with an independent judiciary, or the so-called private sphere with its businesses, organizations, and associations, they do so under the conditions of functional differentiation. In this sense, Niklas Luhmann says "functional differentiation of society also has so strong a hold on world society that it cannot be regionally boycotted by even the most drastic of political and organizational means" (Luhmann, 2012: 92).

The very fact of functional differentiation cannot be "stopped" somewhere at the border. However, it is obvious that the products of function systems, for example, state administrations including armies, companies, banks, universities, civil society organizations, etc., can be controlled by states and their political regimes which control state territories, populations, or resources. The principle of functional differentiation may not be boycotted regionally, but the degree to which it is realized can be controlled by the states of the political world system. States and organized groups of states, for example, are (still) the main spaces where huge organizational capacities are developed to enhance globalization or to control society. These states and organized groups of states can be champions of the free flow of information of goods, persons, and information, as well as policing or even militarizing society in the state territory by closing borders and employing "people control." It follows that, as holders of state power, the state can use state organs and organizations to control other organizations in the territory of their jurisdiction. The degree to which they are able to do this is obviously also dependent on the more-or-less democratic constitution of political power. The degree of democratization also determines the type of relationships states develop as central organizations of the political system with their internal periphery (other political organizations), and with the organizations of other function systems such as the economy (Luhmann, 20oob: 244, Tacke, 2011: 105). This can be clearly seen in certain peripheral regions where certain political regimes are able to undermine or to instrumentalize functional differentiation by "short-circuiting" their own center-periphery relations, either by controlling or eliminating parties or unions, or by conceiving society as an organized body or a hierarchy to be controlled by the Centre (Putin's illusionary ambition). Such strategies could also lead to a kind of "self-peripherization" of political regimes in the sense that they do not allow systems to perform the way they could by politicizing markets, science, education, or art. This may be described as parasiting functional differentiation. Less radical forms may be found in different forms of informal structures, coupled with organizations and networks as Neo-patrimonialism, corruption, or patronage ${ }^{1}$. However, even situations with "failing states," "failed states," "state capture," or the breakdown of regional economic structures

\footnotetext{
1. For these aspects see Hayoz (2016).
} 
after a civil war do not imply that functional differentiation would no longer work ${ }^{2}$. Dedifferentiation processes on a regional level do not question functional differentiation. Regional differences and disparities also imply different conditions for the realization of functional differentiation (Luhmann, 1997a: 811). Regions create favorable or unfavorable conditions for functional differentiation. Countries at the periphery, at war, and/or confronted with multiple crises are obviously less attractive for foreign investments and may have a long way to go before being able to build up performant systems in the spheres of science, education, health, the economy, and so on. For local dictators, it may seem "attractive" to keep their country in a kind of "grey zone" of stagnation with the elites able to "exploit" the peripheral situation of weak institutions while, at the same time, participating in global financial markets (the global economy) and sending their children to the best schools of the world (the global education system). However, such a rationality may backfire when authoritarian structures are breaking down as a result of crisis and protest. Protests against corrupt political structures is a good indicator of a modernity being reclaimed at its periphery.

III

Looking at war and warfare through the lens of Luhmann's systems theory allows us to consider war and the military as part of the communications structure of society. Additionally, in a very basic sense, war as a social construction is always about or starts with communication. It is, particularly nowadays, a matter of communication technologies providing opportunities for informational and electronic deception. It is also a matter of how the electronic media and the Internet transport and present images of war to and in the public space. Consequently, it is also about how states and their regimes communicate about war and peace, presenting events in a way that requires specific political, military, and non-military answers. When used as war propaganda or as an "ideological war," political communication about war is usually being used by a state to mobilize support for specific political objectives, and more generally, to "legitimize" the established power structure. In that sense, war tells us also about how powerful states manipulate information, create enemies, and suppress alternative presentations of political realities.

However, war as communication is also about the social use of the binary distinction of war and peace, and, therefore, about organizations which have to keep and organize the differences between war and peace, the transition from one state to another, and from war to peace or vice versa. This use of the distinction of war and peace established in the political system is obviously regulated by the legal system, especially by the international legal order. With regard to the basic communicative aspect of the distinction, Gorm Harste observes that "War emerged as a codified form of communication. A certain kind of communication emerged as a communication codified according to the central code of war/peace" (Harste, 2004: 161). This raises the question whether and to what extent

2. A point not taken into consideration by certain authors, for example Holzinger (2014: 464f.). 
such a communication can be at the origin of a social system, a so called self-referential warfare or military system (Ibid.: 167). It may be that the military system emerged in the wake of the modern state building as a "sovereign" self-referential system (Ibid.: 175). The code of war and peace of such a system including a historically increasing legal coding could be understood everywhere in Europe. Harste (2009: 4ff.) postulates that even the existence of a war system presented as a function system similar to others such as politics or economy reproduces itself according to its own criteria and is guided by its own semantic forms of self-descriptions (for example, the writings of Clausewitz). The author also underlines the distinction of military systems "as organizational systems, and systems of war and warfare as functional systems" (Ibid.: 5). He is correct in presenting military systems as hierarchically structured organization systems. One can also follow him in his analysis of the supply side of war, the fact that, in the context of European State building, war had to be more and more organized and planned rationally, by involving other social systems in the task. It is no longer simply about counting soldiers, but about the mobilization of the necessary resources and social conditions, including legal ones, to build up efficient military systems. This is what he calls "the sub-differentiation between the systems of financial, legal, material, bureaucratic, political, scientific, educational and cultural supplies for the military system" (Harste, 2004: 158). However, the author is wrong by identifying a war system on the functional level. What would be the societal function of such a system? Which societal problem would be solved on the sole base of the war code of peace/war. In the perspective of systems theory, it does not make sense to put the warfare system on the level of a functional system, where systems are differentiated to fulfill a function for the whole society. The "military form of society" may be coupled to several systems, but this does not mean that a military system could pretend to manage the distinction of war and peace in society. Military systems are organization systems, or combinations of diverse organizations dealing with war and peace. As such, they are serving the function of the political system, which is about adopting collectively binding decisions. As Barbara Kuchler correctly states, the socio-structural place of war is moving to the political system after the passage from stratified society to society differentiated in function systems (Kuchler, 2013a: 508, 2013b: 60). Since politics is about adopting decisions and controlling the monopoly of violence, war, focusing on deciding the issue of conflicts by violence necessarily becomes a political event, with the military a part of a hierarchically organized subsystem of the political system. Under modern conditions of functional differentiation, nation-states are managing the public's degree of inclusion in the function systems which are, in theory accessible to everybody ${ }^{3}$. The inclusion of the public in the political system works through roles such as the citizen-voter who can participate in the election of political personnel, and the citizen-soldier, who has to serve (at least for a period) in the armed forces on the basis of compulsory military service. Such roles can be restricted, extended, or manipulated by the states controlling the population living under its territorial sovereignty. In non-democracies, the meaning-

3. For the inclusion of the soldier role see the analysis of Kuchler (2013b). 
less participation of the public in the political system may be compensated for by other roles such as economic, a privileged access to jobs and services, the soldier role, or even nationalism.

On the other hand, this concentration of the military in the political system also implies considerable interdependencies between the political system responsible for warfare and other function systems, such as the economy or the scientific system. The monopolization of violence combined with the disarmament of the aristocracy by the State also means that war as collective violence is becoming a prerogative of the State (Luhmann, 2ooob: 55, 49) ${ }^{4}$. War is no longer conducted by aristocrats, but by a State whose power is based internally on superior violence, which delegitimizes private violence. Externally, state power has to prove its superiority by conducting war against other powers or nations in order to keep its control over its territory, to expand its territory, or to conquer new resources.

Historically, this was the role the classical Leviathans, the States, have always been playing by imposing peace internally and externally through war or the threat of war, and maintaining peace through military means. Moreover, there is much evidence showing how war has historically made the world more peaceful, confirming the Roman proverb "Si vis pacem para bellum" (Morris, 2014: 393). War can be considered as a powerful catalyst for social and political change, particularly for the formation of the European state nation system (Knöbl, Schmidt, 2000: 16, Sheehan, 2011: 220; Malešević, 2010; Holzinger, 2014). War and military power can be considered as components of the system of modern nation states, and are simply the other side of the successful internal monopolization of legitimate physical violence by the State (Haferkamp, 2000: 103). For Ian Morris (2014), war brought peace through the building up of ever-increasing societies and states, successfully reducing violence. In successfully imposing their monopoly of violence, states and their bureaucracies were the pacifiers guaranteeing peace and order on their territory, making war almost obsolete.

Another aspect of the dialectics between war and peace can be observed in the cooperative aspect of war, or the "military dimension of war" observed by Michel Foucault, pointing to the fact that war always involves cooperative activities on a large scale and complex coordination of organizations. Michael Sheean reformulates this interdependency of war and society paradoxically: "A state at war is also a state at peace" (Sheean, 2011: 219). This is to say that war is unthinkable without organizations. War is about organizing States and societies, "a highly organized and a highly organizing phenomenon" (Sheehan, 2011: 219). The question is not so much about how to prepare or organize war with all the corresponding discourses and political theories about necessary and just wars. It is much more about how to organize society, particularly politics and the economy, in order to be able to make or to avoid war. Organizations are, of course, social systems, as are hierarchically-based communication systems, at least if one looks at society as seen through the concepts of Niklas Luhmann's system theory, as this paper tries to do.

4. Such a perspective is in line with studies of historians and historic sociology on the relationship between state building and war. See Tilly (1990) or Morris (2014). 
To sum up this perspective, we can conclude that "military systems" follow the dominant pattern of society, functional differentiation, and particularly, the development of an autonomous political system. It's states and state-systems control (or trying to control) borders, spaces, and regions, including regional economies that are part of the world economy and finance the ambitions of political regimes with regard to their "military systems." One should also add the importance of the legal system (treaties), and other functional systems such as the education system in regard to war and warfare. War and "military systems" are organizational structures in society which are managed first of all by the political system, which by no means excludes a multiplicity of interdependencies and dependencies from the economy, education, science, or legal system. Forms of selfdescriptions of military systems are not excluded. Even if one wants to identify a kind of "supersystem" in the form of a "military-industrial complex," this would not mean that this would be something which could be put on a societal level. Such an organization at the intersection of organizations of several function systems (the economy, politics, or science, including technology sectors, etc.) could be described as a multiplicity of coordinated organizations and network structures. However, the evocation of a kind of "military-industrial complex" typically evokes the fear and/or the suspicion that "military systems" are too autonomous in society, and are beyond any (democratic) control. However, this could be said of many public and private organizations which have to take the perspectives of several systems into account.

IV

The most famous theories of modern society had always had a blind spot with regard to the sociological analysis of war. Despite the fact that war was and is an important reality worldwide, it was never really on the screens of the observations of Luhmann, Habermas, Parsons, or Bourdieu5. Attempts to revisit the classical "bellicose" tradition of sociology are rather rare. Volker Kruse's study on modernity as war society can be considered as one of these. In the tradition of Spencer's distinction of industrial and military society, the author thinks that modernity should not only be understood as civic society, but also as war society (Kruse, 2009: 199). As a matter of fact, he comes up with the rather surprising idea that modern society cannot be based only on one type of society; it should take into account several types of society (Kruse, 2015: 27ff.). That would mean, and Kruse makes this conclusion, that we have to speak of a double modernity; civic society "face" of modern society, and war society "face." The civic type of society is usually in the focus of sociologists, whereas war society type is rather absent in sociological analysis. For Kruse, war societies can be observed since the French Revolution, reaching their most radical form during the two World Wars, and afterwards in a certain number of countries, particularly socialist ones such as the Soviet Union or China in their experimenting with specific variants of state socialism. According to Kruse, war societies are

5. A fact analyzed particularly by Malešević (2010). 
entities organized by states which are about to prepare for or conducting total war. Big, long, total wars are at the origin of social transformations leading to war societies which develop after the war "return" to civic society type. This is the basic argument in Kruse's approach: despite organized collective violence, the dynamics of big wars creates new structures and orders. A space conditioned by such a dynamic can be called the modernity of war societies (Ibid.: 247).

Kruse's approach is interesting, particularly when looking at the mobilization potential of wars. However, somehow similarly to the already-mentioned case of Harste's description of war, Kruse misunderstands the perspective of a systemic theory of society and the idea of modern society, particularly when this is reduced to the level of a nation or a state mobilizing its resources and organizations against another nation. As a matter of fact, it mixes up organizational and societal levels of system building. Speaking of two types of society as Kruse does make sense precisely on a national and organizational level, but not on the level of society. However, even when identifying "modern civil societies" and "war societies" on the level of a nation, one would have to explain why functional differentiation is seen as being realized in the first, whereas in war societies, a hierarchic mode of differentiation is seen as the main mode of differentiation (Kruse, 2009: 200). By presenting the main features of the military type of society as following the pattern of a military organization, Kruse implicitly admits that we are in the face of "organized society." However, organizations can by no means characterize the main mode of differentiation of modern society. Modern society cannot be reduced to an organizational level. Modern economy cannot be reduced to a bank, law does not exist only in the courts, and politics cannot be reduced to a bureaucracy (although this may be a wish of many dictators!). No single organization can represent the function of the whole function system, or attract all the operations of the system (Luhmann, 1997a: 841). Participation in society cannot be conditioned by membership as it is in the case with organizations. So-called socialist societies may have had the obsession to include the entire population as "members" of the party and its affiliated structures. However, modern society is based on the inclusion of all, whereas organizations imply membership, which means they can discriminate and exclude.

Moreover, it cannot be seen how modern society or modernity could be "doubled" by another type of society. Such errors related to typologies of society have already been made at the time of the Cold War when scholars thought that a different organization of the relationship between capital and labor justified speaking of a "socialist type of society" confronting a "capitalist type of society." Modern society is the reality of functional differentiation, a multiplicity of mutually irreducible differences and orders, and function systems. If this is so, Kruse's question about what happens with functional differentiation in the case of a big war such as the first world is based on a misunderstanding of the very communicative logic of function systems (Kruse, 2009: 204). Apart from the question of the consequences of a total collapse of the world economy, for example, or the more or less total destruction of the planet by nuclear war, it can be seen that even in "war societies" or totalitarian regimes, the reproduction of power, money, law, education, art or 
religion has to be organized, even in "diminished" forms such as politicized structures, or restricted areas controlled by censorship, watchdogs, police and so on.

It follows that when asking, from the perspective of political sociology, how or to what extent the idea of functional differentiation is being "realized," "controlled," "questioned," or even "undermined" on a regional level, one would point first to the states of the political world system. At that regional level, it makes sense to speak of organized societies which are controlled regionally by states (Hayoz, 2007). States and organized groups of states are (still) the main spaces where huge organizational capacities are developed, for example, in order to enhance globalization or to control society. As holders of state power, they can use state organs and organizations to control other organizations in the territory of their jurisdiction. Through certain organizations, more specifically through state bureaucracies, states try to control social order or other social spheres in their territory, using law and money as the main means of communication. States use organizational power to control other organizations such as companies, universities, NGOs, etc., or to control the effects of globalization on their territory. States also need organizational power if they want to control the Internet within the borders of the state territory. As a matter of fact, in many parts of the world, political regimes and their states instrumentalize functional differentiation for political ends. This does not mean that they are able to create something new, or an alternative form of social differentiation through organizational power. States may present themselves as "organized societies" and, in extreme cases, as societies to be "revolutionized" under the guidance of a single party-organization (Luhmann, 2000a: 384 ). The degree to which they are able to control and mobilize organizations for the objectives of the established regime is obviously also dependent on the more or less democratic constitution of political power. The degree of democratization also determines the type of relationship states develop as central organizations of the political system with their internal periphery (other political organizations), and with organizations of other functional systems such as the economy (Luhmann, 200ob: 244, Tacke, 2011: 105).

It is also at the territorial level where states can establish themselves as "war societies" or mobilize military organizations. In fact, their armies or security forces may start a war against an army in another country, to fight against internal enemies in a civil war, or simply to underline their "power projection" on the international scene. Moreover, in a political science perspective, so-called "war societies" can be described as totalitarian or authoritarian regimes. Spencer's military type of society to which Kruse is referring to shows the typical elements of an "organized" or even of a totalitarian state (Kruse, 2009: 200, 2015: $38 \mathrm{ff}$.). Such a state is based on hierarchy, which is the core of organization systems. Furthermore, it is characterized by a strong despotic state, central control, repression, the absence of individual freedoms, and military virtues. On the other hand, the inverse type of society would correspond well to liberal, liberalizing or democratizing regimes and states based on individual freedoms, the absence of repression, a high degree of professional differentiation, contracts, and individualism. A combination of these Spencerian ideal types should be expected. As a matter of fact, one typically may find 
them in authoritarian regimes. In Kruse's perspective, the competition in mobilization is central for war societies. This competition in mobilization defines war and its issues, as World Wars One and Two have shown. The militarization of society is the necessary correlate of such a mobilization of all resources in society. As Kruse correctly states, the reverse of such a mobilization can provoke a dilemma in the sense that mobilization in war society can, if not complete, end up in a military disaster and defeat, or it results in revolutions or breakdown of entire countries through privation and starving of the population (Kruse, 2015: 160ff.)

Of interest here is Kruse's analysis of Stalinism as a renewed variant of total "war society" focusing on modernization, mobilization, and, in the end, war. As a matter of fact, many scholars had already observed the military character of organized society Soviet Union decades ago. In the Soviet Union, forced modernization disguised as industrialization has been used to build up a military or a garrison state based on the militancy of an aggressive ideology, and oriented towards imperial expansion ${ }^{6}$. Other authors have seen a consubstantial aspect of the Soviet empire in the "military statism" (Malia, 1980: 220; Morin, 1983: 193; Kennedy, 1987). Hobsbawm also observed that "the structure of the Soviet system and its modus operandi were essentially military" (Hobsbawm, 1994: 481). The military state points to the objectives of the regime as well as to the instrumentalization of organized society. In supporting this argument, Skidelsky adds that

The most perfectly planned society is an army, and planned societies "whether fascist, communist, or state capitalist all tend to approximate the pattern of military organization: a general staff to do the planning, a hierarchy to command, a rank and file under strict discipline." It is easy to idealize such an order: the civilian is transformed into a civic soldier and endowed with nobler qualities of the military life; he would work not for profit but for the service of the state; he would not indulge the vagaries of the individual mind but think high common thoughts; he would be secure in his status, and 'the whole of which he was a part would be secure because it was disciplined and could therefore be directed without the confusion of debate, of divided opinion, of private ambition, and of private greed. (Skidelsky, 1995: 66)

Such a description corresponds quite well to Kruse's "war society" which, in the case of Soviet Union, could outlast World War Two and continue almost until the breakdown of the Soviet empire. A strange "war society" existed in the "Cold War" period, with actual war not being possible except in the heads of the elites and in the self-description of the Soviet system. However, militancy is not a receipt for regime stability. All exceptional regimes end up in the normality of trivial conflicts of interests and power. Order produces disorder, unity produces conflict. Indeed, the reasons of the breakdown of the Soviet Union have also to be found in the fact that the socialist "war society" and "garrison state" could in the long term not be immunized against external influence or the dynamics of globalization and world society. Three decades ago, certain regions of the world still had reasons to believe that the political and social order built up under the name of

6. For the notion of "garrison state" coming from Spencer, see Janos (1991: 93ff., 97). 
the Soviet empire could last forever. However, the communist "variant of differentiation" based on the communist Ideology, its military power, and the organizational capacities of a single party did not fail simply because it was not able to solve the problems by means of planning and control. It is perhaps a cunning of society that the collapse of the Soviet experiment coincided with the new realities of a globalized world undergoing rapid technological, economic and scientific change, the most visible parts of world society already functionally differentiated. Resisting functional differentiation by isolating whole regions through closing borders and organizing society through hierarchy and peoplecontrol could only work as long and insofar as socialist society could be presented and seen as being without an alternative ${ }^{7}$. Decades ago, Luhmann pointed to the legitimation effects of building the Berlin Wall by the Eastern German communist regime in order to deprive citizens of the possibility of emigrating and contributing to the acceptance of the regime (Luhmann, 2007: 64, N19, and 2009: 217, N14). This would explain partly also why an exceptionally-totalitarian garrison regime such as North Korean can still survive today; a militarized regime based on still-powerful revolutionary war rhetoric can isolate backward society, and avoid the risk of collapse by playing with the risk of war. It is also a reminder of the meanings of the so-called "Cold War." Its alternatives, the risk of destabilization, change, and the very artificial nature of the Soviet variants of differentiation could be made "invisible" by the "Iron Curtain" with the clear message of the permanent risk of war. The Soviet variant of socialism was certainly one of the last political experiments attempting to realize society based on control by one single-party organization. Society cannot not be "organized", even less so from the top of a party structure.

Interestingly enough, a kind of a "military statism" sui generis can also be found in today's Russia. An authoritarian political regime seems to be aiming at again building up elements of a "garrison state," and propagate the image of a "besieged fortress" having to defend its "extensible walls," particularly after Russia’s aggression against Ukraine. This goes together with Putin's reconsolidated state order of the last fifteen years, which, to a certain extent, reproduces Soviet-like organizational structures, and a state capitalism in a globalized context. The 'system of power' established by Putin is a new attempt to control Russian society, its media, its economy, its civil society, and its dynamics by political means, the bureaucracy, and the courts. This corresponds to Russia's ambitions of power as observed in the last decade. The corresponding militarization of society and of the territorial conflicts with or in its "near abroad," particularly in regard to the multiples crises in the Southern Caucasus and the Ukraine, provides the image of society at war in which the semantics of war and the mobilization of patriotism is circulating as necessary parts in the reconstruction of Russia's grandeur ${ }^{8}$.

7. See with this regard Moser (2015) and Hayoz (2007, 1997, 1995).

8. With regard to Russia's imperial ambitions see for example Van Herpen (2015). With regard to the aspect of militarisation see for example Melvin (2014). See also Bouchet (2016). 
Let's face it: despite all of the "peace-enforcing" or "peace-keeping" intentions of the world or regional security organizations, one may simply look at the daily news to conclude that war, including its new forms, is a reality that includes corresponding "military systems," and a permanent risk in a world political system differentiated in states (and only states). It may be that wars as large scale armed conflicts between nations, states, organizations, etc., are in decline in the more-or-less democratized regions of the world, but wars can also come "back" in many different and new forms. This is particularly true at the European periphery, or in third world countries, where one may point to conflicts between different ethnic groups, between national and sub-national entities called quasistates, to conflicts around disputed territories or borders, to state failure, and so on ${ }^{9}$. Moreover, it seems that ideological borders between war and not-war, or war and other forms of armed conflicts such as civil war are becoming blurred. This is also expressed in the new formula of "hybrid war," referring to the fact that non-military aspects such as an "intelligence war" and an "information war," also called a propaganda war, are becoming important tools in the hand of countries such as Russia which are trying to achieve their geopolitical objectives while avoiding the risk of an open-armed conflict ${ }^{10}$. Such aspects have to be considered in the context of a change of warfare resulting from global changes, particularly on the level of communication technologies, which extend the battlefields of the past to the battlespace and cyperspace (Sheehan, 2011: 217). It remains to be seen to what extent such developments, including new forms of war and warfare or the "war" against terrorism, will be able to blur the borders between war and peace, the military sphere and the civil sphere, or between war and crimes (Holzinger, 2014: 471).

However, such considerations are already going beyond the aim of this paper, which strongly supports Luhmann's theory of society, particularly in the demonstration of its explicative potential through the discussion of several studies using elements of Luhmann's theory for the study of war. However, the results of this exploration are rather mixed, not because the theory does not offer adequate conceptual tools, but due to the fact that the studies taken into account do not use the full potential of Luhmann's theory. We have observed this critically, particularly with regard to the essential difference between the level of society, where function systems have to been "situated," and the level of organizations (hierarchy, membership) which is also the "social place" of "military systems." This could also be said of some of the critics of the theory of functional differentiation who do not seem to understand that the systemic perspective offers a multiplicity of concepts, types, and analytical levels for the description not only for world society, but also its regional "expressions" or a phenomenon like wars and "military systems" in specific states or groups of states ${ }^{11}$. Such a confusion can also be partly explained by the fact

9. See on the question of declining number of wars and the rise of new forms of conflicts Tertrais (2010), Morris (2014), Münkler (2015), English (2013).

10. A point particularly relevant and underlined by Marc Galeotti (2015) in the case of Russias covert intervention or adventure in Eastern Ukraine. See also Münkler (2015) and particularly IISS (2015).

11. See Holzinger (2015) for example and his inadequate critics of Kuchler's study of war. 
that mainstream sociology continues to think of society in terms of a national or regional society. In such a perspective, the example of the "socialist experiment" of the 20 th century is considered as being something different and is not being analyzed as a distorted variant of modernity, where modernity is understood as world society with functional differentiation and based on specific coupling of function systems and organizations, particularly those party organizations attempting to control society. A deep understanding of Luhmann's theory of society allows one to distinguish the communicative reality of society with its different levels, and the spatial realities of regional developments where function systems have to be accepted or perhaps undermined. In addition, one may point to the case of China shedding its peripheral status, and soon becoming an economic and political world power. China is certainly an excellent example of an efficient and powerful combination of the use of universal functions systems and regional peculiarities with a communist party trying to control the dynamics of the function systems. It is also a good example of an authoritarian regime trying to block certain social developments (human rights), and a rising military regime building up "military systems" which are about to be perceived as a threat to its neighbors.

Finally, taking into account the worldwide realization of functional differentiation and the fact that states are the dominant structure dividing the world territory in bigger or smaller segments with protected borders, it can be seen how regional political systems are using organizations and their resources to build up specific "military systems." With this process, these political regimes organizing political power in a democratic or nondemocratic way are also reproducing corresponding semantics and discourses (including "war memories," "ideological wars," enemies, etc.) which may or may not be used as both part of a legitimation strategy and to strengthen national identity. Complex "military systems" would not be possible without such organizations, particularly state bureaucracies and affiliated organizations.

\section{References}

Bouchet N. (2016) Russia's "Militarization" of Colour Revolutions. Policy Perspectives, vol. 4, no 2. https://www.ethz.ch/content/dam/ethz/special-interest/gess/cis/centerfor-securities-studies/pdfs/PP4-2.pdf (accessed 6 May 2016).

English R. (2013) Modern War: A Very Short Introduction, Oxford: Oxford University Press.

Galeotti M. (2015) "Hybrid War" and "Little Green Men": How It Works, and How It Doesn't. Ukraine and Russia: People, Politics, Propaganda and Perspectives (eds. A. Pikulicka-Wilczewska, R. Sakwa), Bristol: E-International Relations, pp. 156-164.

Haferkamp H. (2000) Kriegsfolgen und gesellschaftliche Wandlungsprozesse. Die Gegenwart des Krieges (Hrsg. W. Knöbl, G. Schmidt), Frankfurt am Main: Fischer, S. 102-124. 
Harste G. (2004) Society's War: The Evolution of a Self-Referential Military System. Observing International Relations: Niklas Luhmann and World Politics (eds. M. Albert, L. Hilkermeier), London: Routledge, S. 157-176.

Harste G. (2009) Linking Political Systems and War Systems: Systemic Risks, Paradoxes and Blind Spots. Forum on Public Policy, no 1. Available at: http://forumonpublicpolicy.com/springogpapers/archivesprog/harste.pdf (accessed 20 March 2016).

Hayoz N. (1995) Dédifferenciations régionales et différences fonctionnelles universelles. Soziale Systeme, no 2, pp. 261-282.

Hayoz N. (1997) L'Etreinte soviétique, Genève: Droz.

Hayoz N. (2007) Regionale "organisierte Gesellschaften" und ihre Schwierigkeiten mit der Realitat der funktionalen Differenzierung. Soziale Systeme, Jg. 13, Heft 1-2, S. $160-172$.

Hayoz N. (2016) Informal Networks of Power and Control of Deviation in Post-Soviet Non-Democracies. International Relations and Diplomacy, vol. 4, no 1, pp. 60-69.

Hobsbawm E. J. (1994) Age of Extremes: The Short Twentieth Century 1914-1991, London: Michael Joseph.

Holzinger M. (2014) Niklas Luhmanns Systemtheorie und Kriege. Zeitschrift für Soziologie, Jg. 43, Heft 6, S. 458-475.

IISS (2015) The Military Balance 2015, London: Routledge

Janos A. C. (1986) Politics and Paradigms: Changing Theories of Change in Social Science, Stanford: Stanford University Press

Kennedy P. (1987) The Rise and Fall of the Great Powers, New York: Random House.

Knöbl W., Schmidt G. (2000) Einleitung: Warum brauchen wir eine Soziologie des Krieges? Die Gegenwart des Krieges (Hrsg. W. Knöbl, G. Schmidt), Frankfurt am Main: Fischer, S. 7-24.

Kruse V. (2009) Mobilisierung und kriegsgesellschaftliches Dilemma: Beobachtungen zur kriegsgesellschaftlichen Moderne. Zeitschrift für Soziologie, Jg. 38, Heft 3, S. 198214.

Kruse V. (2015) Kriegsgesellschaftliche Moderne, Konstanz: UVK Verlagsgesellschaft.

Kuchler B. (2013a) Krieg und gesellschaftliche Differenzierung. Zeitschrift für Soziologie, Jg. 42, Heft 6, S. 502-520.

Kuchler B. (2013b) Kriege: Eine Gesellschaftstheorie gewaltsamer Konflikte, Frankfurt am Main: Campus.

Luhmann N. (1990) Essays on Self-Reference, New York: Columbia University Press.

Luhmann N. (1982) The Differentiation of Society, New York: Columbia University Press.

Luhmann N. (1984) Soziale Systeme: Grundriss einer allgemeinen Theorie, Frankfurt: Suhrkamp.

Luhmann N. (1997a) Die Gesellschaft der Gesellschaft, Frankfurt am Main: Suhrkamp.

Luhmann N. (1997b) Globalization or World Society: How to Conceive of Modern Society? International Review of Sociology, vol. 7, no 1, p. 67-79.

Luhmann N. (2000a) Organisation und Entscheidung, Wiesbaden: Westdeutscher Verlag. Luhmann N. (20oob) Die Politik der Gesellschaft, Frankfurt am Main: Suhrkamp. 
Luhmann N. (2007) Politische Planung: Aufsätze zur Soziologie von Politik und Verwaltung, Wiesbaden: VS.

Luhmann N. (2009) Soziologische Aufklärung 1: Aufsätze zur Theorie sozialer Systeme, Wiesbaden: VS.

Luhmann N. (2012) Theory of Society, Vol. 1, Stanford: Stanford University Press.

Luhmann N. (2013) Theory of Society, Vol. 2, Stanford: Stanford University Press.

Malia M. (1980) Comprendre la Révolution Russe, Paris: Seuil.

Malešević S. (2010) The Sociology of War and Violence, Cambridge: Cambridge University Press.

Melvin N. (2014) The Galloping Militarisation of Eurasia. openDemocracy, 16 June 2014. Available at: https://www.opendemocracy.net/od-russia/neil-melvin/galloping-militarisation-of-eurasia (accessed 8 May 2016).

Morin E. (1983) De la nature de l'URSS, Paris: Fayard.

Morris I. (2014) War: What Is It Good for? London: Profile Books.

Moser E. (2015) Postsowjetische Transformationen in der Weltgesellschaft: Politische Dezentralisierung und wirtschaftliche Differenzierung im ländlichen Russland, Bielefeld: transcript.

Münkler H. (2015) Das Chamäleon Krieg und der Kampf um eine neue Weltordnung. Testfall Ukraine Europa und seine Werte (Hrsg. K. Raabe, M. Sapper), Frankfurt am Main: Suhrkamp, pp. 177-19o.

Sheehan M. (2011) The Changing Character of War. The Globalization of World Politics (eds. J. Baylis, S. Smith, P. Owens), Oxford: Oxford University Press, pp. 214-229.

Skidelsky R. (1995) The World after Communism: A Polemic for Our Times, London: MacMillan.

Stichweh R. (2000) Die Weltgesellschaft, Frankfurt am Main: Suhrkamp

Stichweh R. (2006) Strukturbildung in der Weltgesellschaft: Die Eigenstrukturen der Weltgesellschaft und die Regionalkulturen der Welt. Die Vielfalt und Einheit der Moderne (Hg. Th. Schwinn), Wiesbaden: VS, S. 239-258.

Tacke V. (2011) Soziale Netzwerkbildungen in Funktionssystemen der Gesellschaft: Vergleichende Perspektiven. Netzwerke in der funktional differenzierten Gesellschaft (Hrsg. M. Bommes, V. Tacke), Wiesbaden: VS, S. 89-118.

Tertrais B. (2014) La Guerre: Que sais-je? Paris: PUF.

Tilly Ch. (1990) Coercion, Capital, and European States, AD 990-1990, Oxford: Blackwell. Van Herpen M. H. (2015) Putin's Wars: The Rise of Russia's New Imperialism, New York: Rowman \& Littlefield. 


\section{Организация войны и военные в обществе: системная перспектива}

\section{Николя Айо}

Доцент кафедры политологии, директор Междисциплинарного института Центральной и Восточной Европы в Университете Фрибура (Швейцария)

Адрес: Bd de Pérolles 90, 1700 Fribourg, Switzerland

E-mail: nicolas.hayoz@unifr.ch

Социология может анализировать войну с различных сторон, например, как проблему коллективного насилия. Достаточно часто игнорировался еще один важный аспект войны тот факт, что она всегда еще и организационное явление. В последнее время некоторые исследования войны фокусировались на данном аспекте, используя или упоминая системную теорию Н. Лумана. В настоящей статье критически рассматривается некоторые из этих исследований с точки зрения того, как теория Лумана используется при анализе войны или связанных с войной социальных структур. Теория Лумана, в частности, его теория общества, основанного на принципе функциональной дифференциации, обладает мощным объяснительным потенциалом, в особенности для анализа войны и военных действий. Однако лишь немногие исследования действительно адекватно применяют теорию Лумана, располагая понятия на должном аналитическом уровне. Война и «военные системы» должны быть проанализированы как организационные структуры общества, управление которыми осуществляется, в первую очередь, политической системой - функциональной системой общества, которая, в свою очередь, никоим образом не исключает множества взаимосвязей с другими системами. Системная перспектива должна также учитывать региональные особенности общества, такие, как «военные системы» в конкретных государствах или объединениях государств.

Ключевые слова: война, организация, теории систем, Никлас Луман, военные системы, военное общество, милитаризация, функциональная дифференциация 